\title{
Synthesis of Methyl Methacrylate From Coal-Derived Syngas
}

\author{
Quarterly Report \\ October 1 - December 31, 1997
}

Work Performed Under Contract No.: DE-AC22-94PC94065

\author{
For \\ U.S. Department of Energy \\ Office of Fossil Energy \\ Federal Energy Technology Center \\ P.O. Box 880 \\ Morgantown, West Virginia 26507-0880
}

By

Research Triangle Institute

3040 Cornwallis Road

P. O. Box 12194

Research Triangle Park, North Carolina 27709-2194 


\section{Disclaimer}

This report was prepared as an account of work sponsored by an agency of the United States Government. Neither the United States Government nor any agency thereof, nor any of their employees, makes any warranty, express or implied, or assumes any legal liability or responsibility for the accuracy, completeness, or usefulness of any information, apparatus, product, or process disclosed, or represents that its use would not infringe privately owned rights. Reference herein to any specific commercial product, process, or service by trade

name, trademark, manufacturer, or otherwise does not necessarily constitute or imply its endorsement, recommendation, or favoring by the United States Government or any agency thereof. The views and opinions of authors expressed herein do not necessarily state or reflect those of the United States Government or any agency thereof. 


\begin{abstract}
Research Triangle Institute (RTI), Eastman Chemical Company, and Bechtel collectively are developing a novel process for the synthesis of methyl methacrylate (MMA) from coal-derived syngas that consists of three steps of synthesis of a propionate, its condensation with formaldehyde, and esterification of resulting methacrylic acid (MAA) with methanol to produce MMA. Over the last quarter, Eastman developed two new processes which have resulted in two new invention reports. One process deals with carbonylation of benzyl ether which represents a model for coal liquefaction and the second focuses on the acceleration of carbonylation rates for propionic acid synthesis, via use of polar aprotic solvents. These two inventions are major improvements in the novel Mo-catalyzed homogeneous process for propionic acid synthesis technology, developed by Eastman.

Over the last quarter, RTI completed three reaction cycles and two regeneration cycles as a part of long-term reaction regeneration cycle study on a $10 \% \mathrm{Nb}_{2} \mathrm{O}_{5} / \mathrm{SiO}_{2}$ catalyst, for vapor phase condensation reaction of formaldehyde with propionic acid. The reaction cycles were carried out at the following conditions: $\mathrm{T}=300{ }^{\circ} \mathrm{C}, \mathrm{P}=2 \mathrm{~atm}, 5 \mathrm{~g}$ (16-30 mesh size) catalyst charge, 72:16:220 mmol/h PA:HCHO: $\mathrm{N}_{2}$. The regeneration cycle was performed overnight following a reaction cycle, under the following conditions: $\mathrm{T}=400{ }^{\circ} \mathrm{C}, \mathrm{P}=2 \mathrm{~atm}, 46: 174 \mathrm{mmol} / \mathrm{h} \mathrm{O}_{2}: \mathrm{N}_{2}$. The purpose of this long term study is to examine the changes in the activity and its relation to size of the $\mathrm{Nb}_{2} \mathrm{O}_{5}$ crystallite, as a function of time. The results of the long-term reaction regeneration cycle study show the following:
\end{abstract}

\title{
During the first cycle:
}

- $\quad$ MAA yield (based on charged $\mathrm{HCHO}) \quad=39.4 \rightarrow 24.5 \%$

- $\quad$ MAA yield (based on charged PA) $\quad=7.90 \rightarrow 5.07 \%$

- $\quad$ MAA rate $(\mathrm{mmol} / \mathrm{g}$ cat. $\mathrm{h}) \quad=1.29 \rightarrow 0.88 \mathrm{mmol} / \mathrm{g}$ cat. $\mathrm{h}$

\section{During the second cycle:}

$\begin{array}{lll}- & \text { MAA yield (based on charged } \mathrm{HCHO}) & =35.7 \rightarrow 18.2 \% \\ - & \text { MAA yield (based on charged PA) } & =7.05 \rightarrow 4.11 \% \\ - & \text { MAA rate (mmol/g cat. } \mathrm{h}) & =1.08 \rightarrow 0.76 \mathrm{mmol} / \mathrm{g} \text { cat. } \mathrm{h}\end{array}$

\section{At the conclusion of the third cycle:}

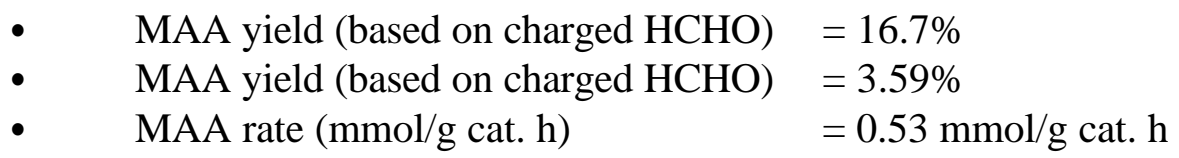

The results show the first regeneration cycle is effective in restoring the catalyst activity (MAA yield is restored 90.6\%.) However, $\mathrm{CO}, \mathrm{DEK}$, and $\mathrm{CO}_{2}$ rates show increasing trends, compared to first cycle. After the second regeneration, the MAA yield does not recover at all, and MAA yield continues to rise slowly during about $25 \mathrm{~h}$ on stream, during the third cycle. At the conclusion of the third cycle, with about $75 \mathrm{~h}$ on stream, the MAA yield is $16.7 \%$, and MAA rate 
is at $0.53 \mathrm{mmol} / \mathrm{g}$ cat. $\mathrm{h}$. However, the $\mathrm{CO}, \mathrm{CO}_{2}$, and $\mathrm{DEK}$ rates are all very high, compared to the MAA rate, and therefore the run is discontinued at this point. The reasons for catalyst deactivation are currently being elucidated.

RTI has concurrently worked on and completed the design of a fixed-bed microreactor system for DME partial oxidation reactions, and examined the flammability limits of DME/oxygen and DME/air mixtures, to ensure the operational safety of DME reactor. 


\section{TABLE OF CONTENTS}

Page

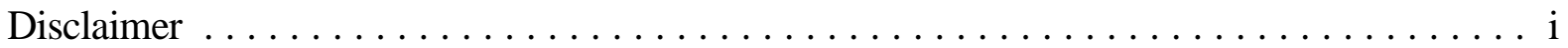

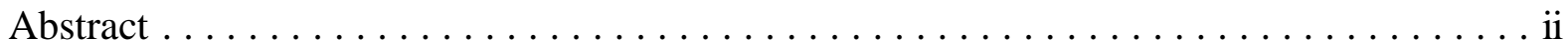

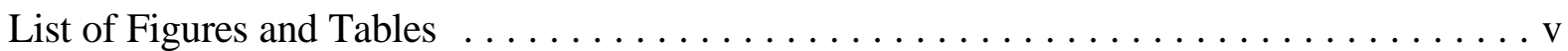

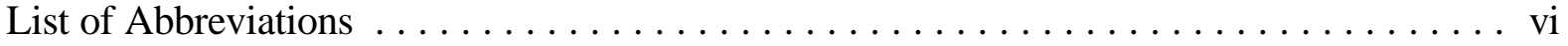

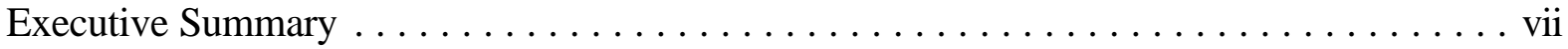

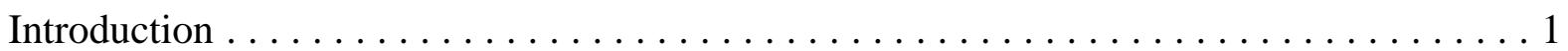

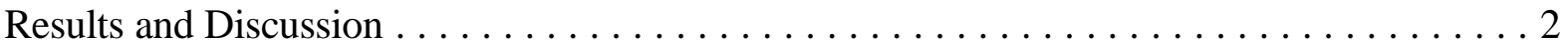

Task 1. Propionate Synthesis (Eastman and Bechtel) $\ldots \ldots \ldots \ldots \ldots \ldots \ldots . \ldots \ldots$

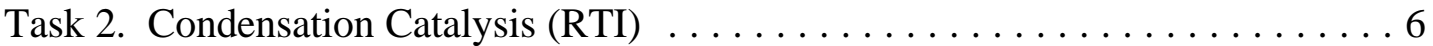

Task 3. Slurry Reactor Studies (RTI and Eastman) $\ldots \ldots \ldots \ldots \ldots \ldots \ldots$

Task 4. DME Feedstock Evaluation (RTI and Eastman) $\ldots \ldots \ldots \ldots \ldots \ldots$

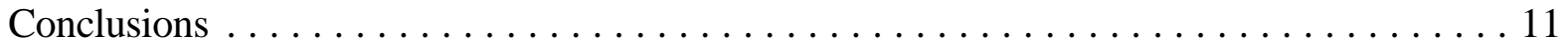

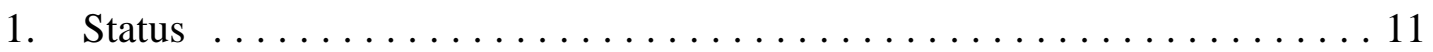

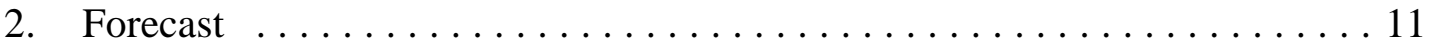

References ........................................... 12 


\section{LIST OF FIGURES}

Number

Page

1 The RTI-Eastman-Bechtel three-step MMA process (with external

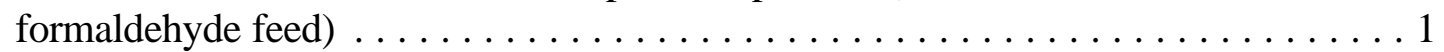

2 Reaction pathway for carbonylation of dibenzyl ether $\ldots \ldots \ldots \ldots \ldots \ldots$

3 Mechanism for fragmentation of dibenzyl ether $\ldots \ldots \ldots \ldots \ldots \ldots \ldots$

4 Reaction-regeneration cycle study on a $10 \% \mathrm{Nb}_{2} \mathrm{O}_{5} / \mathrm{SiO}_{2}$ catalyst - MAA yields for first reaction cycle $\ldots \ldots \ldots \ldots \ldots \ldots \ldots$

5 Reaction-regeneration cycle study on a $10 \% \mathrm{Nb}_{2} \mathrm{O}_{5} / \mathrm{SiO}_{2}$ catalyst - MAA, $\mathrm{CO}, \mathrm{CO}_{2}$, and DEK rates for first reaction cycle $\ldots \ldots \ldots \ldots 7$

6 Reaction-regeneration cycle study on a $10 \% \mathrm{Nb}_{2} \mathrm{O}_{5} / \mathrm{SiO}_{2}$ catalyst - MAA yields for first and second reaction cycles $\ldots \ldots \ldots \ldots \ldots$

7 Reaction-regeneration cycle study on a $10 \% \mathrm{Nb}_{2} \mathrm{O}_{5} / \mathrm{SiO}_{2}$ catalyst - MAA, $\mathrm{CO}, \mathrm{CO}_{2}$, and DEK rates for first and second reaction cycles . . . 8

8 Reaction-regeneration cycle study on a $10 \% \mathrm{Nb}_{2} \mathrm{O}_{5} / \mathrm{SiO}_{2}$ catalyst - MAA yields for first three reaction cycles . . . . . . . . . . . 9

9 Reaction-regeneration cycle study on a $10 \% \mathrm{Nb}_{2} \mathrm{O}_{5} / \mathrm{SiO}_{2}$ catalyst - MAA, $\mathrm{CO}, \mathrm{CO}_{2}$, and DEK rates for first three reaction cycles $\ldots \ldots \ldots 10$

\section{LIST OF TABLES}

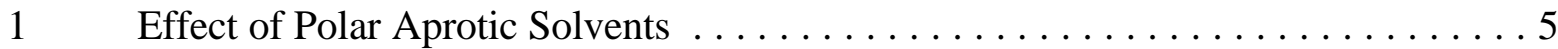




\section{LIST OF ABBREVIATIONS}

$\begin{array}{ll}\mathrm{ACH} & \text { Acetone cyanohydrin } \\ \mathrm{Bu}_{4} \mathrm{PBr} & \text { Tetrabutyl phosphonium bromide } \\ \mathrm{CO} & \text { Carbon monoxide } \\ \mathrm{CO}_{2} & \text { Carbon dioxide } \\ \mathrm{DEK} & \text { Diethyl ketone } \\ \mathrm{DME} & \text { Dimethyl ether } \\ \mathrm{DOE} & \text { U.S. Department of Energy } \\ \text { FETC } & \text { Federal Energy Technology Center } \\ \mathrm{HCHO} & \text { Formaldehyde } \\ \mathrm{MAA} & \text { Methacrylic acid } \\ \mathrm{Mo} & \text { Molybdenum } \\ \mathrm{MMA} & \text { Methyl methacrylate } \\ \mathrm{MP} & \text { Methyl propionate } \\ \mathrm{Nb}_{2} \mathrm{O}_{5} & \text { Niobium (V) oxide } \\ \mathrm{N}_{2} & \text { Nitrogen } \\ \mathrm{PA}_{\mathrm{PhCHO}} & \text { Propionic acid } \\ \mathrm{PhCH}_{2} \mathrm{Br} & \text { Benzaldehyde } \\ \mathrm{PhCH}_{2} \mathrm{OCH} \mathrm{Ph}_{2} & \text { Benzyl bromide } \\ \mathrm{PhCH}_{2} \mathrm{COOCH}_{2} \mathrm{Ph} & \text { Dibenzyl ether } \\ \mathrm{Ph}_{\left(\mathrm{CH}_{2}\right)_{2} \mathrm{Ph}} & \text { Benzyl phenyl acetate } \\ \mathrm{PhMe}_{\mathrm{SiO}} & \text { Toluene } \\ \mathrm{Si}_{2} & \text { Silica }\end{array}$




\section{EXECUTIVE SUMMARY}

The Research Triangle Institute (RTI)-Eastman-Bechtel team is developing a novel process for the synthesis of methyl methacrylate (MMA) from coal-derived syngas. The three-step process consists of synthesis of a propionate, its condensation with formaldehyde to produce methacrylic acid (MAA), and esterification of MAA with methanol to yield MMA. Based on a preliminary economic analysis, the RTI three-step route is competitive with five other commercial or nearcommercial technologies for MMA manufacture.

Over the last quarter, Eastman developed two new processes which have resulted in two new invention reports. One process deals with carbonylation of benzyl ether which represents a model for coal liquefaction and the second focuses on the acceleration of carbonylation rates for propionic acid synthesis, via use of polar aprotic solvents. These two inventions are major improvements in the novel Mo-catalyzed homogeneous process for propionic acid synthesis technology, developed by Eastman.

Over the last quarter, RTI completed two reaction cycles and two regeneration cycles for a longterm reaction regeneration cycle study on a $10 \% \mathrm{Nb}_{2} \mathrm{O}_{5} / \mathrm{SiO}_{2}$ catalyst, for vapor phase condensation of formaldehyde with propionic acid. The results of the long-term reaction regeneration cycle study show that:

\section{During the first cycle:}

- MAA yield (based on charged HCHO)

$$
\begin{aligned}
& =39.4 \rightarrow 24.5 \% \\
& =7.90 \rightarrow 5.07 \% \\
& =1.29 \rightarrow 0.88 \mathrm{mmol} / \mathrm{g} \text { cat. } \mathrm{h}
\end{aligned}
$$

\section{During the second cycle:}

- MAA yield (based on charged HCHO) $\quad=35.7 \rightarrow 18.2 \%$

- MAA yield (based on charged PA) $\quad=7.05 \rightarrow 4.11 \%$

- MAA rate (mmol/g cat. h)

$$
=1.08 \rightarrow 0.76 \mathrm{mmol} / \mathrm{g} \text { cat. } \mathrm{h}
$$

\section{At the conclusion of the third cycle:}

- MAA yield (based on charged HCHO) $\quad=16.7 \%$

- MAA yield (based on charged HCHO) $=3.59 \%$

- MAA rate $(\mathrm{mmol} / \mathrm{g}$ cat. $\mathrm{h}) \quad=0.53 \mathrm{mmol} / \mathrm{g}$ cat. $\mathrm{h}$

The results show the first regeneration cycle is effective in restoring the catalyst activity (MAA yield is restored 90.6\%.) However, $\mathrm{CO}, \mathrm{DEK}$, and $\mathrm{CO}_{2}$ rates show increasing trends, compared to first cycle. After the second regeneration, the MAA yield does not recover at all, and it continues to rise slowly during about $25 \mathrm{~h}$ on stream, during the third cycle. At the conclusion of the third cycle, with about $75 \mathrm{~h}$ on stream, the MAA yield is $16.7 \%$, and MAA rate is at 0.53 $\mathrm{mmol} / \mathrm{g}$ cat. h. However, the $\mathrm{CO}, \mathrm{CO}_{2}$, and DEK rates are all very high, compared to the MAA 
rate, and therefore the long-term reaction-regeneration cycle run is discontinued after the third cycle. The reasons for catalyst deactivation are currently being elucidated.

RTI has also concurrently worked on and completed the design of a fixed-bed microreactor system for DME partial oxidation reactions. RTI has also examined the flammability limits of DME/oxygen and DME/air mixtures, to ensure that reaction studies are conducted safely. 


\section{INTRODUCTION}

The most widely practiced commercial technology for the synthesis of methacrylic acid (MAA) and methyl methacrylate (MMA) is the acetone cyanohydrin $(\mathrm{ACH})$ process. The $\mathrm{ACH}$ process requires handling of large quantities of extremely toxic and hazardous hydrogen cyanide and generates copious amounts of ammonium sulfate wastes that are either discarded or reclaimed at substantial cost. The ACH technology is currently environmentally and economically untenable for any new expansions, primarily because of the cost of either disposing or regenerating the bisulfate waste.

There is a strong drive within the chemical industry for a replacement process for MMA synthesis (Spivey et al., 1995, 1996a, 1996b). There is a particular interest in the process that is not petroleum-based, but rather based on domestically produced coal-based syngas. The Research Triangle Institute (RTI)-Eastman-Bechtel three-step process (shown schematically in Figure 1) is comprised of the following steps:

Step 1: Propionate synthesis from ethylene (1) and ethylene plus propionic acid (2)

$$
\begin{gathered}
\mathrm{H}_{2} \mathrm{C}=\mathrm{CH}_{2}+\mathrm{CO}+\mathrm{H}_{2} \mathrm{O} \rightarrow \mathrm{CH}_{3} \mathrm{CH}_{2} \mathrm{COOH} \\
\mathrm{CH}_{3} \mathrm{CH}_{2} \mathrm{COOH}+\mathrm{CO}+\mathrm{H}_{2} \mathrm{C}=\mathrm{CH}_{2} \rightarrow\left(\mathrm{CH}_{3} \mathrm{CH}_{2} \mathrm{CO}\right)_{2} \mathrm{O}
\end{gathered}
$$

Step 2: Condensation of propionate with formaldehyde

$$
\begin{gathered}
\left(\mathrm{CH}_{3} \mathrm{CH}_{2} \mathrm{CO}\right)_{2} \mathrm{O}+\mathrm{HCHO} \rightarrow \mathrm{CH}_{2}=\mathrm{C}\left(\mathrm{CH}_{3}\right) \mathrm{COOH}+\mathrm{CH}_{3} \mathrm{CH}_{2} \mathrm{COOH} \\
\mathrm{CH}_{3} \mathrm{CH}_{2} \mathrm{COOH}+\mathrm{HCHO} \rightarrow \mathrm{CH}_{2}=\mathrm{C}\left(\mathrm{CH}_{3}\right) \mathrm{COOH}+\mathrm{H}_{2} \mathrm{O}
\end{gathered}
$$

$$
\left(\mathrm{CH}_{3} \mathrm{CH}_{2} \mathrm{CO}\right)_{2} \mathrm{O}+2 \mathrm{HCHO} \rightarrow 2 \mathrm{CH}_{2}=\mathrm{C}\left(\mathrm{CH}_{3}\right) \mathrm{COOH}+\mathrm{H}_{2} \mathrm{O}
$$

Step 3: Esterification with methanol

$$
\mathrm{CH}_{2}=\mathrm{C}\left(\mathrm{CH}_{3}\right) \mathrm{COOH}+\mathrm{CH}_{3} \mathrm{OH} \rightarrow \mathrm{CH}_{2}=\mathrm{C}\left(\mathrm{CH}_{3}\right) \mathrm{COOCH}_{3}+\mathrm{H}_{2} \mathrm{O}
$$

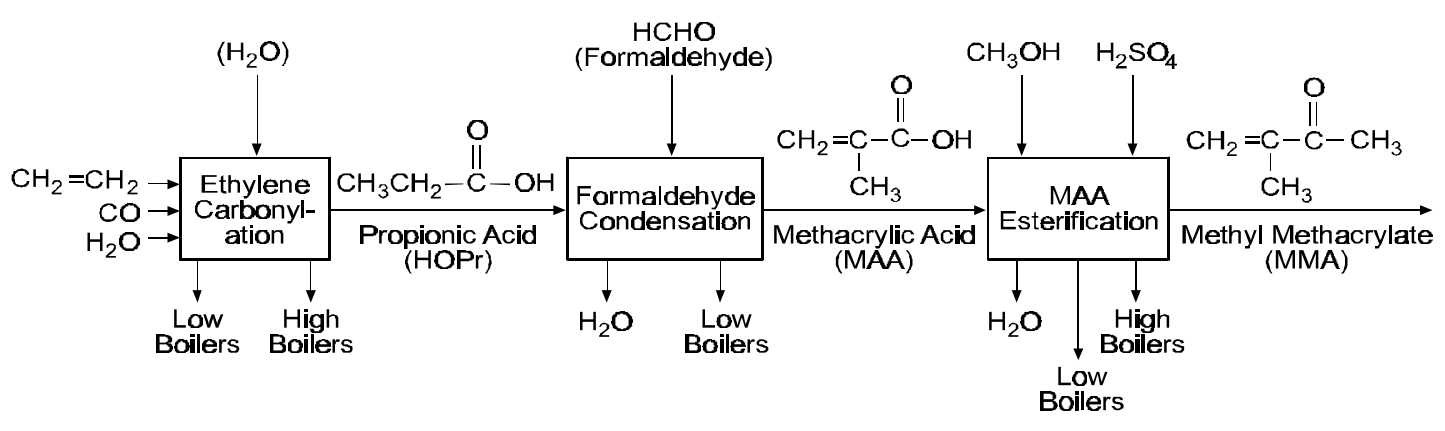

Figure 1. The RTI-Eastman-Bechtel three-step MMA process (with external formaldehyde feed). 
In this proposed process for MMA manufacture, Step 3 is a known art. Steps 1 and 2, however, present a challenge for successful commercial demonstration of the process.

The first two steps have been the focus of the RTI-Eastman-Bechtel team research effort. This original RTI-Eastman-Bechtel three-step route to MMA (shown schematically in Figure 1) uses methanol to generate $\mathrm{HCHO}$ in the external $\mathrm{HCHO}$ generation step. This $\mathrm{HCHO}$ is subsequently condensed with PA, and the resulting MAA is externally esterified with methanol to form MMA. Under an extension of this original contract, the RTI-Eastman-Bechtel research team will also study the use of DME, instead of methanol, to generate formaldehyde, either externally or in situ. Methyl propionate (MP) will be used as the propionyl source, in stead of PA. The DME-based route produces MMA in one step, and is therefore deemed to be a cost-effective alternative to the methanol-based route.

\section{RESULTS AND DISCUSSION}

\section{Task 1. Propionate Synthesis (Eastman and Bechtel)}

Eastman has completed the experimental work and economic analysis for the overall process, and have completed their share of responsibilities per the statement of work for the original contract. The results have been included in earlier reports. Comprehensive account of Eastman's research has been summarized in an earlier DOE report (Annual Technical Report, 1997).

Over the last quarter, Eastman has developed two new processes which have resulted in two invention reports. One process deals with the carbonylation of benzyl ether using Mo based carbonylation catalyst, and the other with acceleration of Mo catalyzed ethylene carbonylation using polar aprotic solvents. Further details have been summarized below:

\section{Dibenzyl Ether}

Attempted carbonylation of dibenzyl ether using the Mo based carbonylation catalyst, which was so useful for ethylene carbonylation, fails to carbonylate nonolefinic substrates. Although most are inert to the carbonylation conditions, dibenzyl ether was unique in that it fragmented. The results of dibenzyl ether carbonylation are shown in Figure 2, where the abbreviations for chemical compounds are: $\mathrm{PhCH}_{2} \mathrm{OCH}_{2} \mathrm{Ph}$, dibenzyl ether; $\mathrm{Bu}_{4} \mathrm{PBr}$, tetrabutyl phosphonium bromide; $\mathrm{PhCH}_{2} \mathrm{Br}$, benzyl bromide; $\mathrm{PhCHO}$, benzaldehyde; $\mathrm{PhMe}$, toluene; $\mathrm{Ph}\left(\mathrm{CH}_{2}\right)_{2} \mathrm{Ph}, 1,2$ diphenyl ethane; $\mathrm{PhCH}_{2} \mathrm{COOCH}_{2} \mathrm{Ph}$, benzyl phenyl acetate.

$$
\begin{aligned}
& \mathrm{Mo}(\mathrm{CO})_{6} \text {, } \\
& \mathrm{PhCH}_{2} \mathrm{OCH}_{2} \mathrm{Ph} \underset{5 \mathrm{~h}, 160^{\circ} \mathrm{C}, 300 \mathrm{psi} \mathrm{CO}}{\longrightarrow} \\
& \mathrm{PhCHO}+\mathrm{PhMe}+\mathrm{PhCH}_{2} \mathrm{CH}_{2} \mathrm{Ph}+\mathrm{PhCH}_{2} \mathrm{COOCH}_{2} \mathrm{Ph} \\
& (78 \%) \quad(85 \%) \quad(3 \%) \quad(3 \%)
\end{aligned}
$$

Reaction pathway for carbonylation of dibenzyl ether.

Figure 2. 
The overall conversion of dibenzyl ether is $51 \%$, and at $175{ }^{\circ} \mathrm{C}$, the overall conversion is $83 \%$, based on recovered dibenzyl ether. The fragmentation of dibenzyl ether to benzaldehyde and toluene is a known free radical process and this represents further evidence that the ethylenebased carbonylation process is a free radical initiated process. This fragmentation is of particular interest in coal liquefaction as the benzyl ether linkage is regarded as the key linkage that must be broken in coal liquefaction. This represents a $>200^{\circ} \mathrm{C}$ improvement over the known Mo-S and $\mathrm{Fe}-\mathrm{S}$ catalysts used to date which are believed to follow a similar path. The mechanism of dibenzyl ether fragmentation is shown in Figure 3.

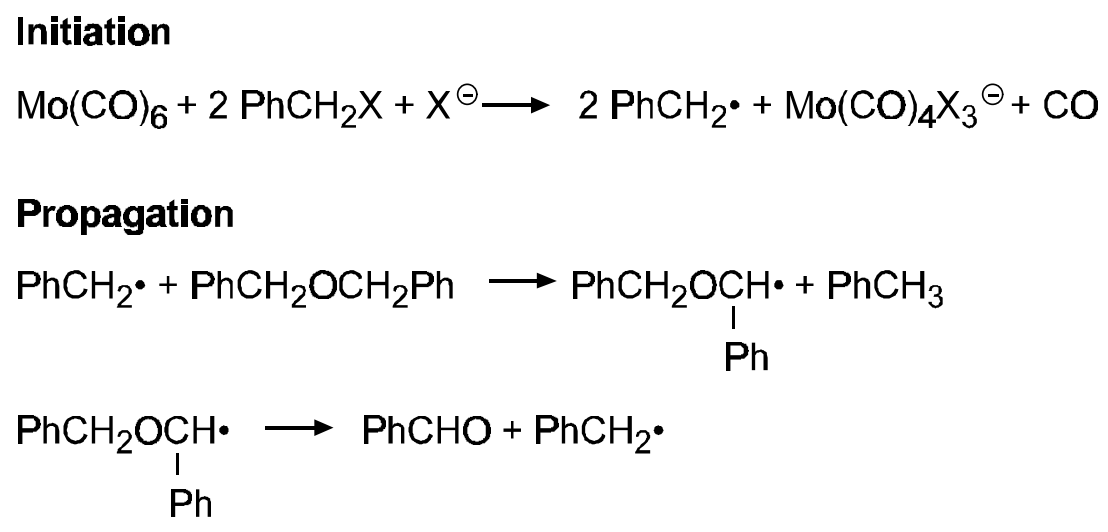

Termination

$2 \mathrm{PhCH}_{2} \cdot \longrightarrow \mathrm{PhCH}_{2} \mathrm{CH}_{2} \mathrm{Ph}$

Figure 3. Mechanism for fragmentation of dibenzyl ether.

\section{Acceleration of Mo Catalyzed Ethylene Carbonylation Using Polar Aprotic Solvents}

In our earlier reports, we described the mechanism for the Mo catalyzed carbonylation of ethylene to propionic anhydride and acid, and subsequently published the results of this study (Zoeller et al., 1997) Within the discussion of the mechanism, we described the likelihood that the initial removal of halide involved an inner-sphere, electron transfer process based on the low halide effect and interference from other ligands. Although there was some uncertainty due to the further involvement of halide in later parts of the mechanism, electron transfer processes are known to be accelerated by polar aprotic solvents. When these are added to the reaction, generally in relatively small amounts, the reactions are accelerated markedly. This indicates that the reaction likely does proceed via an electron transfer and improves the process rate markedly.

The most important breakthrough was in the synthesis of propionic acid. Whereas the propionic acid process without the polar aprotic solvent is relatively slow and we needed to run the reaction at higher temperatures to obtain measurable (and marginally useful industrial) rates, the addition of a polar aprotic solvent now runs at acceptable rates at the same temperature used for the anhydride process. This represents a rate acceleration in the propionic acid process of greater than an order of magnitude. An added advantage is that we can now get away from using complex 
quaternary ammonium and phosphonium salts, using sodium instead, and still achieve acceptable rates. An exemplary procedure is attached and the results are tabulated below.

\section{Example 1. General Procedure}

Generation of Propionic Anhydride with an N-Methyl Pyrrolidinone Accelerated Mo(CO) $\mathrm{Bu}_{4}$ PI Catalyst. To allow the measurement of rates, a 2 L Hastelloy ${ }^{\circledR} \mathrm{C}$ overhead stirred autoclave was fitted with a high-pressure condenser and a dip tube for removing samples during the course of the reaction. Gas mixtures were prepared in a stirred gas mix tank heated to 45$50{ }^{\circ} \mathrm{C}$ and feed lines were heat traced and maintained at $40-50{ }^{\circ} \mathrm{C}$. Failure to keep the mix tank and lines heated often leads to ethylene liquefaction and separation, particularly when cooling begins to occur (due to expansion) as ethylene is either added to the tank during preparation of the gas mixture or as it is removed from the tank during the reaction. The following procedure is exemplary of a typical operation for the generation of propionic anhydride.

To the autoclave was added $5.81 \mathrm{~g}(0.022 \mathrm{~mol})$ of $\mathrm{Mo}(\mathrm{CO})_{6}, 15.5 \mathrm{~g}(0.040 \mathrm{~mol})$ of tetrabutylphosphonium iodide, $109.2 \mathrm{~g}(0.700 \mathrm{~mol})$ of ethyl iodide, $555 \mathrm{~g}(7.5 \mathrm{~mol})$ of propionic acid, and $68.6 \mathrm{~g}$ of $\mathrm{N}$-methyl pyrrolidinone (NMP) as solvent. The condenser temperature is set at $5-10{ }^{\circ} \mathrm{C}$ using a cooled ethylene glycol/water mixture. The autoclave was then pressure tested with nitrogen at $68.0 \mathrm{~atm}$ and a gas purge of $3 \mathrm{~mol} / \mathrm{h}$ of gas was established through the high pressure condenser. (During the reaction this gas purge permitted control of the gas composition over the reaction mixture and is necessary for kinetic measurements.) The nitrogen was vented, the autoclave was then pressurized to $23.8 \mathrm{~atm}$ with $5 \%$ hydrogen in carbon monoxide, and subsequently heated to $160{ }^{\circ} \mathrm{C}$. (The $3 \mathrm{~mol} / \mathrm{h}$ of gas purge is maintained throughout heating and the subsequent reaction.) Upon reaching temperature, the pressure is raised to $51.0 \mathrm{~atm}$ using a gas mixture consisting of $6 \% \mathrm{H}_{2}, 47 \% \mathrm{CO}$, and $47 \%$ ethylene while using the $3 \mathrm{~mol} / \mathrm{h}$ purge to maintain the gas mixture. Liquid samples are removed every 20 minutes for 5 hours and analyzed for ethyl iodide, ethyl propionate, propionic anhydride, and propionic acid content by GC using a Hewlett Packard 5890 GC containing a 25-m (0.25-mm ID, 0.25- $\mu \mathrm{m}$ film) Quadrex 007 FFAP Capillary Column with $p$-xylene as an internal standard. (A split injection was used to introduce the sample and sample detection was accomplished with TCD detector.) These components represented the only significant products and all other materials detectable by GC-MS were only present at trace levels. Gas samples were also removed hourly and analyzed by GC to ensure that the gas mixture is consistent. The molar quantities of propionic anhydride $\left(\mathrm{n}_{\mathrm{pan}}\right)$ formed were determined from the GC data using the following equation:

$$
\mathrm{n}_{\mathrm{pan}}=\frac{\mathrm{X}_{\mathrm{pan}}}{130}, \frac{\mathrm{n}_{\mathrm{pa}}{ }^{\mathrm{o}}+\mathrm{n}_{\mathrm{ei}}{ }^{\mathrm{o}}}{\left[\left(\mathrm{X}_{\mathrm{ei}} / 156\right)+\left(\mathrm{X}_{\mathrm{pa}} / 74\right)+\left(\mathrm{X}_{\mathrm{pan}} / 130\right)+\left(\mathrm{X}_{\mathrm{ex}} / 102\right)\right]}
$$

where:

$$
\begin{aligned}
& \mathrm{n}_{i}=\text { moles of the component } \\
& \mathrm{X}_{i}=\text { weight fraction of the component (obtained from GC analysis) } \\
& \mathrm{n}_{\mathrm{pa}}{ }^{\circ}=\text { moles of propionyl initially present }
\end{aligned}
$$


$\mathrm{n}_{\mathrm{ei}} \mathrm{o}^{\mathrm{O}}=$ ethyl iodide initially added

$\mathrm{Wt}=$ Weight of reaction mixture

with subscript designations being:

$$
\begin{aligned}
& \text { ep }=\text { ethyl propionate } \\
& \text { pa }=\text { propionic acid } \\
& \text { pan }=\text { propionic anhydride } \\
& \text { ei }=\text { ethyl iodide }
\end{aligned}
$$

The molar quantities were plotted against time and the reaction displayed an essentially linear behavior from about 20 minutes into the reaction until the conversion of propionic acid approached ca. 65-70\% where the effects of dilution start to become apparent. (The 20-minute "lag" is not due to an "initiation" period, but represents the time it takes to replace the $\mathrm{H}_{2} / \mathrm{CO}$ gas mix within the autoclave with the reaction mixture of ethylene/CO/ $\mathrm{H}_{2}$.) Therefore, the rate of the reaction (expressed as moles of propionic anhydride formed $/ \mathrm{kg}$ of initial reaction solution/h) was easily determined by using a best fit slope of this plot until either the 5-h reaction period had expired or the conversion reached $65 \%$. Using this method, the rate of propionic anhydride formation was determined to be $3.4 \mathrm{~mol} / \mathrm{kg}$ initial solution $/ \mathrm{h}$ (440 g/kg initial solution-h).

\section{Comparative Example 1. Effect of Polar Aprotic Solvent - Generation of Propionic Anhydride with an $\mathrm{Mo}(\mathrm{CO})_{6}-\mathrm{Bu}_{4}$ PI Catalyst in the Absence of a Polar Aprotic Solvent.}

Example 1 was repeated except the NMP was omitted. The reaction rate was only $1.4 \mathrm{~mol} / \mathrm{kg}$ initial solution/h (180 g/kg initial solution-h). The results have been summarized in Table 1 .

Table 1. Effect of Polar Aprotic Solvents ${ }^{\#}$

\begin{tabular}{ccc}
\hline $\begin{array}{c}\text { Polar Aprotic Solvent } \\
\text { Added }\end{array}$ & $\begin{array}{c}\text { Salt or Group 15 } \\
\text { Compound }\end{array}$ & Rate (mol/kg-h) \\
\hline None & Bu4PI $^{\mathrm{a}}$ & 1.4 \\
NMP & Bu4PI & 3.4 \\
Sulfolane & Bu4PI & 2.7 \\
None & Bu4NI & 1.1 \\
NMP & Bu4NI & 5.4 \\
None & NaI & 0.8 \\
NMP & NaI & 2.3 \\
None & pyridine & 2.2 \\
NMP & pyridine & 3.8 \\
NMP & Bu4PI & $2.2\left(160{ }^{\circ} \mathrm{C}\right)$ \\
None $^{\mathrm{a}}$ & Bu4PI & $0.6\left(175^{\circ} \mathrm{C}\right)$ \\
\hline
\end{tabular}

"Propionic Acid Process (ethylene, CO, water), process proceeds at $<0.2 \mathrm{~mol} / \mathrm{kg}-\mathrm{h}$ at $160{ }^{\circ} \mathrm{C}$.

${ }^{\mathrm{a}}$ Tetra n-butyl phosphonium iodide, ${ }^{\mathrm{b}}$ Tetra n-butyl ammonium iodide, ${ }^{\mathrm{c}}$ Sodium iodide. 


\section{Task 2. Condensation Catalysis (RTI)}

The condensation of formaldehyde with propionic acid is a synthetic route to MAA and MMA. The reaction is considered to be acid-base catalyzed (Gogate et al., 1996, 1997a, 1997b). As a result of screening over 81 catalysts, Group V metals including vanadium, niobium, and tantalum have been shown to be effective condensation catalysts. The performance of a 20-percent $\mathrm{Nb} / \mathrm{SiO}_{2}$ catalyst, in terms of formaldehyde and propionic acid conversions and MAA selectivity, at nominal operating conditions of $300{ }^{\circ} \mathrm{C}, 2 \mathrm{~atm}$, mole flow rates of PA:HCHO: $\mathrm{N}_{2}=72: 16: 220$ $\mathrm{mmol} / \mathrm{h}, 5-\mathrm{g}$ (16-30 mesh size) catalyst charge, and a volume hourly space velocity of $1,080 \mathrm{~cm}^{3} / \mathrm{g}$ cat $\cdot h$ has been demonstrated to be the most superior, among the catalysts tested.

RTI is currently studying the effect of reaction-regeneration cycles on the crystallite size of $10 \%$ $\mathrm{Nb}_{2} \mathrm{O}_{5} / \mathrm{SiO}_{2}$ catalyst at the following conditions: $\mathrm{T}=300{ }^{\circ} \mathrm{C}, \mathrm{P}=2$ atm, 5-g (16-30 mesh size) catalyst charge, and 72:16:220 mmol/h PA:HCHO: $\mathrm{N}_{2}$, with trioxane as the formaldehyde source. The results of the first reaction cycle have been summarized in Figures 4 and 5. Figure 4 shows the MAA yield (based on charged $\mathrm{HCHO}$ and PA) as a function of time over the course of first reaction cycle. The MAA yield declined from $39.5 \%$ to $24.4 \%$ (based on $\mathrm{HCHO}$ ) and from $7.9 \%$ to $5.1 \%$ (based on PA). Likewise, the MAA rate dropped from 1.29 to $0.94 \mathrm{mmol} / \mathrm{g}$ cat.h, as shown in Figure 5. The carbon dioxide $\left(\mathrm{CO}_{2}\right)$ and diethyl ketone (DEK) rates were practically unchanged at $0.56 \mathrm{mmol} / \mathrm{g}$ cat.h and $0.076 \mathrm{mmol} / \mathrm{g}$ cat.h, respectively, during the first cycle. The $\mathrm{CO}$ rate increases from 0.29 to $0.61 \mathrm{mmol} / \mathrm{g}$ cat.h. Apparently, the decline in MAA rate is accompanied by an increase in $\mathrm{CO}$ rate (probably from $\mathrm{HCHO}$ decomposition).

Following this first reaction cycle, it was decided to stop the reaction study and to regenerate the catalyst. This regeneration cycle was performed overnight under the following conditions: $\mathrm{T}=$ $400{ }^{\circ} \mathrm{C}, \mathrm{P}=2 \mathrm{~atm}, 46: 174 \mathrm{mmol} / \mathrm{h} \mathrm{O}_{2}: \mathrm{N}_{2}$. After the regeneration cycle, the second reaction cycle was begun on this catalyst. The results of the first and second reaction cycle together have been summarized in Figures 6 and 7. Figure 6 shows the MAA yield (based on charged HCHO and $\mathrm{PA}$ ) as a function of time. The MAA yield declined from $35.8 \%$ to $18.2 \%$ (based on $\mathrm{HCHO}$ ) and from $7.05 \%$ to $4.11 \%$ (based on PA), during the second reaction cycle. Likewise, the MAA rate dropped from 1.08 to $0.77 \mathrm{mmol} / \mathrm{g}$ cat.h. The $\mathrm{CO}$ rate continued to increase from 0.61 to 1.65 $\mathrm{mmol} / \mathrm{g}$ cat.h, as shown in Figure 7.

The results of the first and second reaction cycles show that:

- $\quad$ MAA yield is restored to about $90.6 \%$ of the original value, upon first regeneration.

- Catalyst loses more activity in the second reaction cycle (from $35.8 \%$ to $18.2 \%$, a fractional change of 0.51 ), compared to the first reaction cycle (from $39.5 \%$ to $24.5 \%$, a fractional change of 0.62 )

- The $\mathrm{CO}$ rate increases by a factor of 2 for the first reaction cycle (from 0.29 to 0.61 $\mathrm{mmol} / \mathrm{g}$ cat. h), it increases by nearly a factor of 2.3 for the second reaction cycle (from 0.61 to $1.65 \mathrm{mmol} / \mathrm{g}$ cat. $\mathrm{h}$ ).

- The $\mathrm{CO}_{2}$ rate also shows a weak increasing pattern, although clearly it is not as pronounced as the $\mathrm{CO}$ rate. 


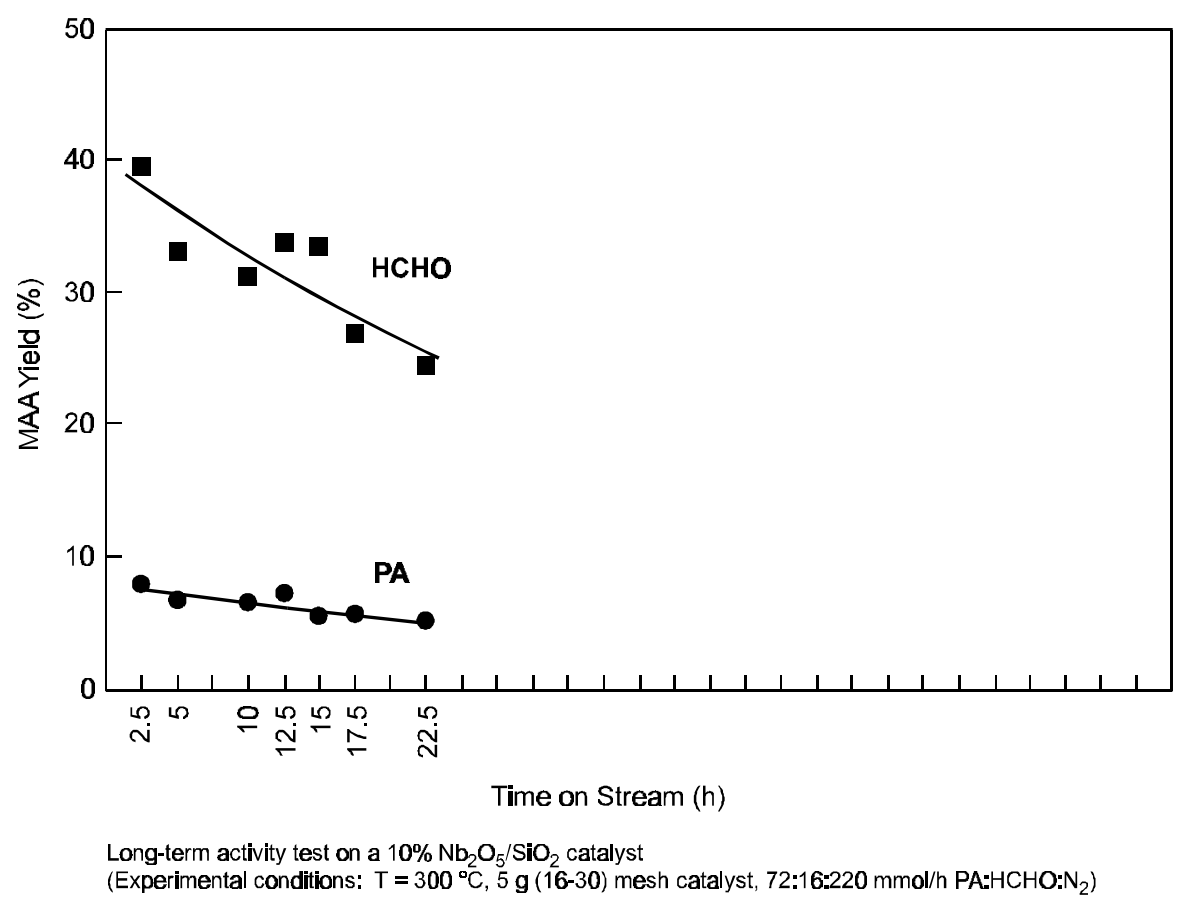

Figure 4. Reaction-Regeneration Cycle Study on a $10 \% \mathrm{Nb}_{2} \mathrm{O}_{5} / \mathrm{SiO}_{2}$ catalyst - MAA Yields for first reaction cycle.

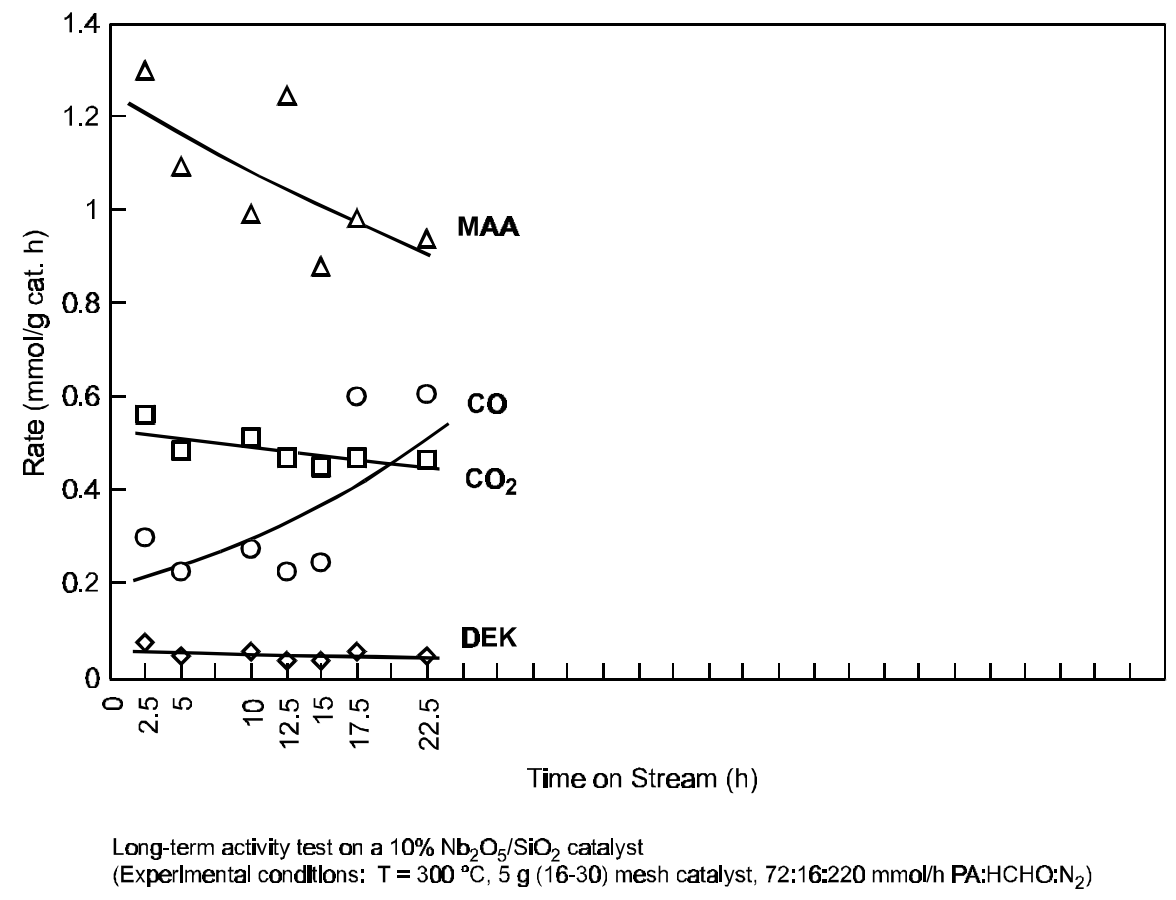

Figure 5. Reaction-Regeneration Cycle Study on a $10 \% \mathrm{Nb}_{2} \mathrm{O}_{5} / \mathrm{SiO}_{2}$ catalyst MAA, CO, $\mathrm{CO}_{2}$, and DEK Rates for first reaction cycle. 


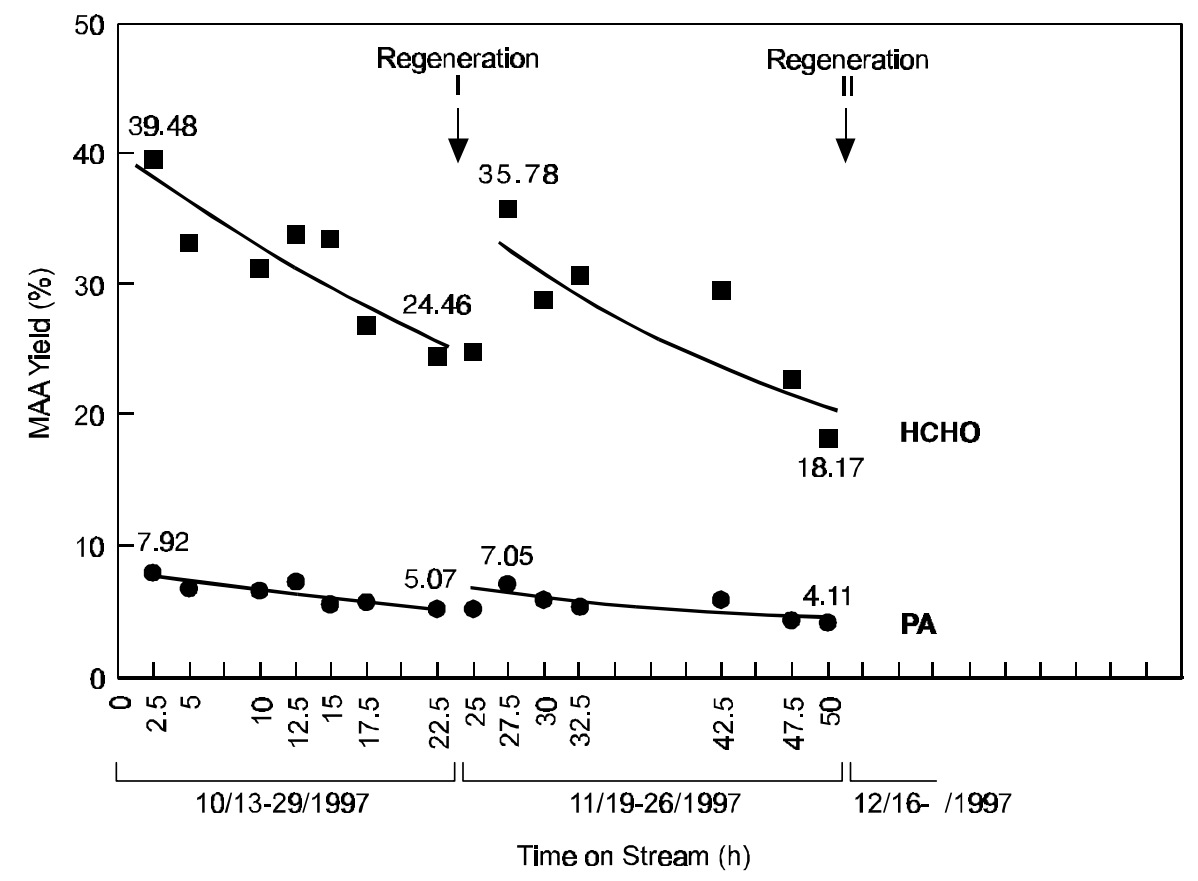

Long-term activity test on a $10 \% \mathrm{Nb}_{2} \mathrm{O}_{5} / \mathrm{SiO}_{2}$ catalyst

(Experimental conditions: $\mathrm{T}=300^{\circ} \mathrm{C}, 5 \mathrm{~g}(16-30)$ mesh catalyst, $72: 16: 220 \mathrm{mmol} / \mathrm{h}$ PA:HCHO: $\mathrm{N}_{2}$ )

Figure 6. Reaction-Regeneration Cycle Study on a $10 \% \mathrm{Nb}_{2} \mathrm{O}_{5} / \mathrm{SiO}_{2}$ catalyst - MAA Yields for first and second reaction cycles.

Reaction-
ion Cycle
$10 \%$
catalyst
$\mathrm{CO}, \mathrm{CO}_{2}$,
Rates for
second
cycles.

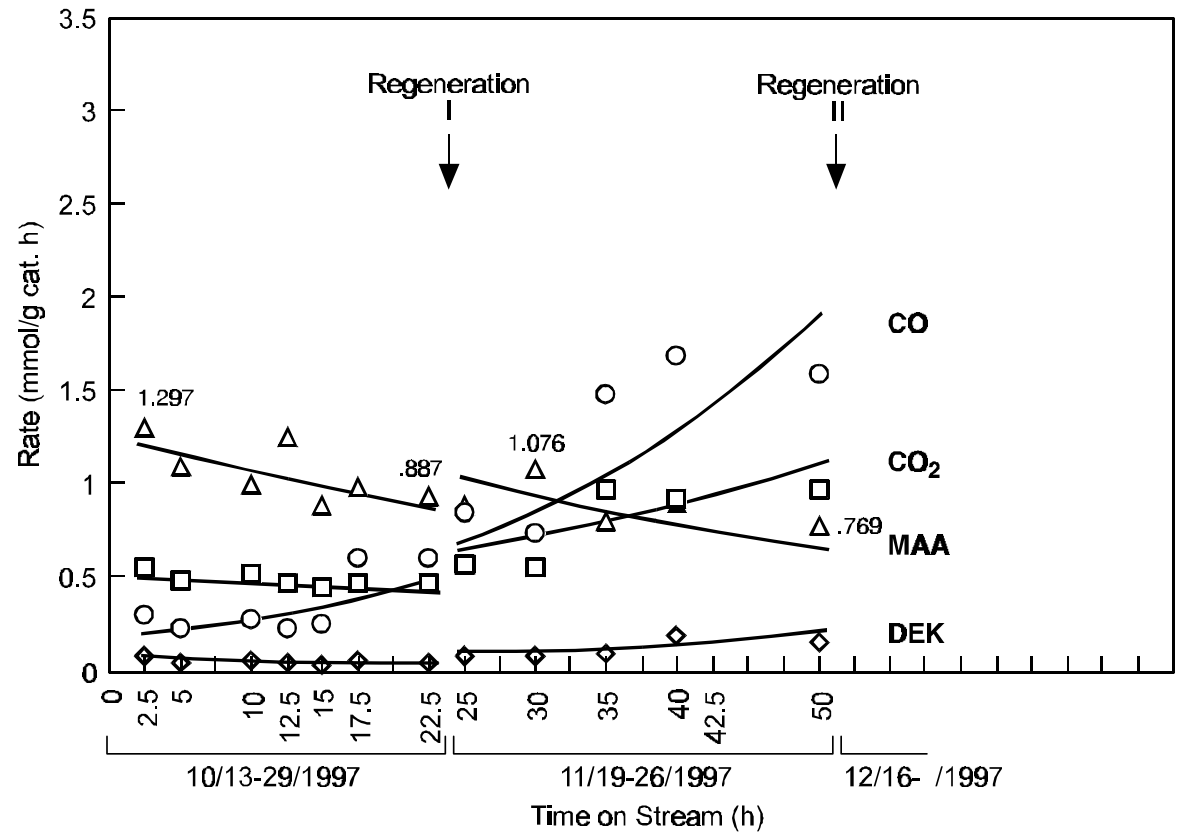

Long-term activity test on a $10 \% \mathrm{Nb}_{2} \mathrm{O}_{5} / \mathrm{SiO}_{2}$ catalyst

(Experimental conditions: $\mathrm{T}=300^{\circ} \mathrm{C}, 5 \mathrm{~g}(16-30)$ mesh catalyst, $72: 16: 220 \mathrm{mmol} / \mathrm{h} \mathrm{PA}: \mathrm{HCHO}: \mathrm{N}_{2}$ )

Figure 7. Regenerat Study on a $\mathrm{Nb}_{2} \mathrm{O}_{5} / \mathrm{SiO}_{2}$

- MAA, and DEK first and reaction

After the second reaction cycle, the catalyst was again regenerated, and a third reaction cycle was carried out on this catalyst. The results of all three reaction cycles collectively are shown in 
Figures 8 and 9. Figure 8 shows the MAA yields based on $\mathrm{HCHO}$ and PA, and Figure 9 shows the MAA, $\mathrm{CO}, \mathrm{CO}_{2}$, and DEK rates as a function of time-on-stream.

Since it appeared that the catalyst shows a steady decline in the MAA yield and rate over time, and a gradual increase in $\mathrm{CO}, \mathrm{CO}_{2}$, and DEK rates, coupled with the fact that the third reaction did not achieve the same level of MAA yields and rates as the first and second reaction cycles, it was decided to stop the experimental run. The deactivated catalyst is currently being analyzed by several techniques including BET- $\mathrm{N}_{2}, \mathrm{Hg}$-porosimetry, XRD, XPS/ESCA (at Eastman), and acidbase properties to elucidate the causes of catalyst deactivation. Currently, experiments with methyl propionate as the propionyl feedstock instead of propionic acid, are being conducted on the $10 \% \mathrm{Nb}_{2} \mathrm{O}_{5} / \mathrm{SiO}_{2}$ catalyst in support of a patent application. A new catalyst based on an alkali metal supported on an amorphous support is also currently being synthesized for vapor phase condensation reactions.

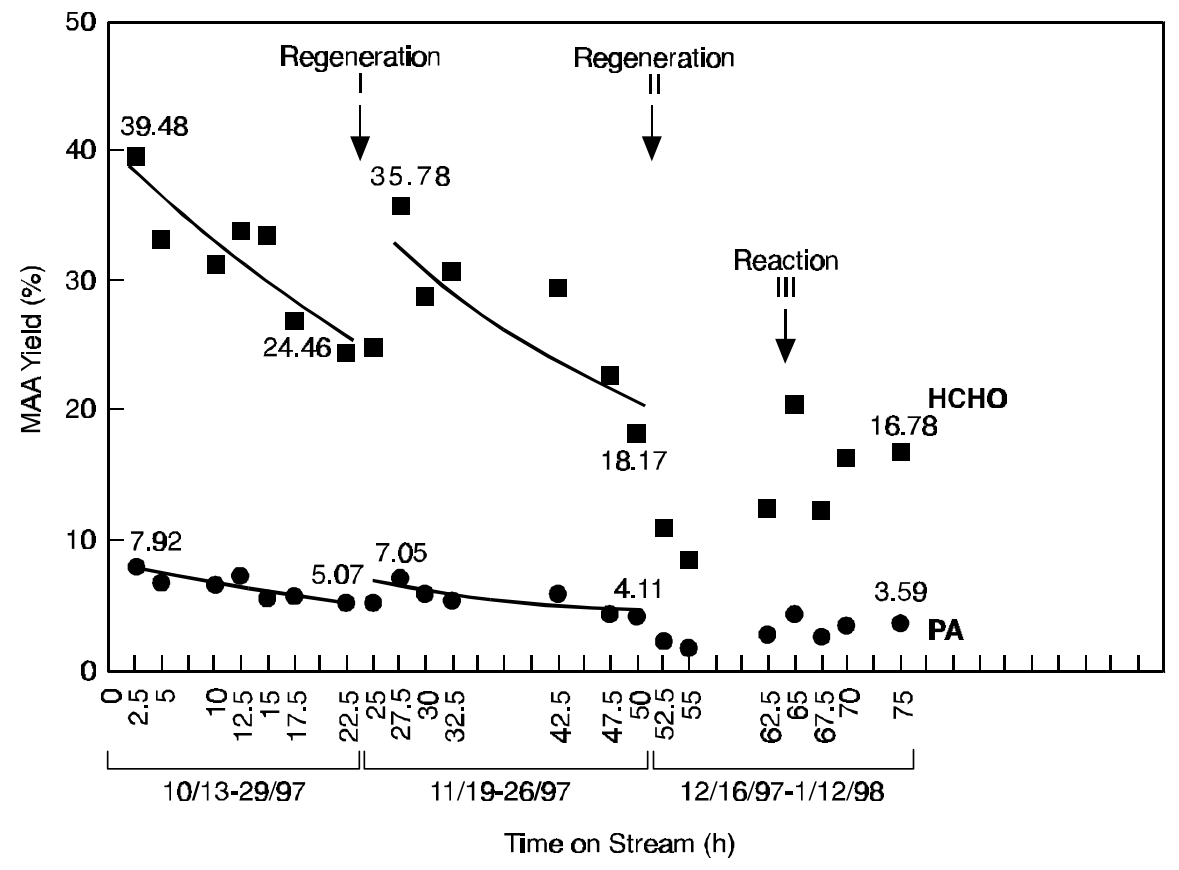

Long-term activity test on a $10 \% \mathrm{Nb}_{2} \mathrm{O}_{5} / \mathrm{SiO}_{2}$ catalyst

Figure (Experimental conditions: $\mathrm{T}=300^{\circ} \mathrm{C}, 5 \mathrm{~g}(16-30)$ mesh catalyst, 72:16:220 mmol/h PA:HCHO: $\mathrm{N}_{2}$ ) 8 .

Reaction-Regeneration Cycle Study on a $10 \% \mathrm{Nb}_{2} \mathrm{O}_{5} / \mathrm{SiO}_{2}$ catalyst

- MAA yields for first three reaction cycles. 


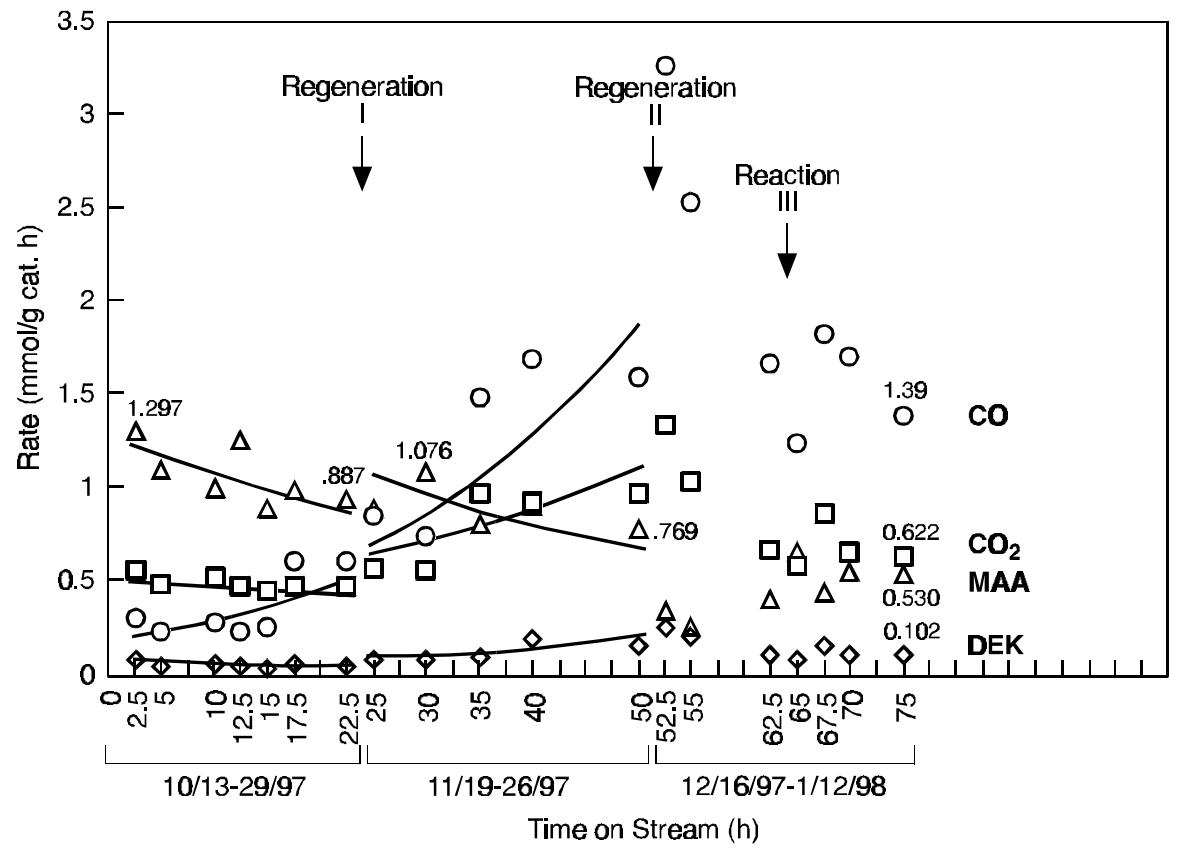

Long-term activity test on a $10 \% \mathrm{Nb}_{2} \mathrm{O}_{5} / \mathrm{SiO}_{2}$ catalyst

(Experimental conditions: $\mathrm{T}=300^{\circ} \mathrm{C}, 5 \mathrm{~g}(16-30)$ mesh catalyst, $72: 16: 220 \mathrm{mmol} / \mathrm{h}$ PA: $\mathrm{HCHO}: \mathrm{N}_{2}$ )

Figure 9. Reaction-Regeneration Cycle Study on a $10 \% \mathrm{Nb}_{2} \mathrm{O}_{5} / \mathrm{SiO}_{2}$ catalyst - MAA, CO, $\mathrm{CO}_{2}$, and DEK Rates for first three reaction cycles.

\section{Task 3. Slurry Reactor Studies (RTI and Eastman)}

Based on Eastman's economic analysis (presented in annual report for FY 1997), the in situ slurry reactor process development studies were deemphasized in favor of the more attractive RTI three-step route. The slurry reactor technology will likely be revisited at the end of the dimethyl ether (DME) extension of this contract (slated for completion on March 31, 1999).

\section{Task 4. DME Feedstock Evaluation (RTI and Eastman)}

The DME extension of the current contract on synthesis of acrylates and methacrylates from coalderived syngas began on April 1, 1997. This extension increases the period of performance to March 31, 1999, and focuses on studying the use of DME rather than methanol as a source of formaldehyde. The original RTI three-step route uses propionic acid as the propionyl source and an external formaldehyde source (generated from methanol). The DME route (which is the subject of the contract extension) uses MP as the propionyl source and DME/methanol partial oxidation reaction as the formaldehyde source (either in situ or external).

RTI has begun the research on the DME route and completed the design of a fixed-bed microreactor system for DME partial oxidation reaction and DME-MP condensation reactions. The schematic of the fixed-bed reactor system has been given in a previous quarterly report. RTI is also working on catalyst synthesis for DME partial oxidation reactions. Initial catalysts for DME partial oxidation studies will be based on tungsten oxide $\left(\mathrm{WO}_{3}\right)$ supported on silica, based on literature results. RTI has also examined the flammability limits for DME-air and DME-oxygen 
mixtures to ensure that DME partial oxidation reactor operates outside these limits. The flammability diagrams were also given in a previous report.

\section{CONCLUSIONS}

\section{Status}

Task 1 (Propionate Synthesis) and Task 2 (Condensation Catalysis) are complete. Task 3 (Slurry Reactor Studies) is on hold and will likely be revisited during the DME extension or upon its completion. Over the last quarter, RTI has completed the long-term reaction regeneration cycle study on the $10 \% \mathrm{Nb}_{2} \mathrm{O}_{5} / \mathrm{SiO}_{2}$ catalyst. The results show that under trioxane conditions, the first and second reaction cycles at $300{ }^{\circ} \mathrm{C}$ and 2 atm over $50 \mathrm{~h}$ on-stream show comparable yield of MAA, based on charged HCHO and PA. The first regeneration carried out after $25 \mathrm{~h}$ on-stream restored about $90.6 \%$ of catalyst activity. The second regeneration which was carried out after $50 \mathrm{~h}$ on stream was not effective, however. The MAA yield did not during the third cycle did not recover to original values, and $\mathrm{CO}, \mathrm{CO}_{2}$, and DEK rates also showed increasing trends. Therefore the long-term study was discontinued at this point.

During the last quarter, Eastman also developed two major new processes; one for fragmentation of benzyl ether which represents a model for coal liquefaction, and the second for acceleration of carbonylation processes by polar aprotic solvents. Both these inventions represent major innovations in propionic acid synthesis technology in development at Eastman.

The catalyst synthesis plan for DME partial oxidation reactions have been formulated. Initial catalysts will be based on tungsten oxide/silica system, based on earlier results from the literature. The flammability limits for DME-air and DME-nitrogen system have been studied, to ensure the operational safety of DME partial oxidation reactor.

\section{Forecast}

Current research on the RTI three-step route focuses on:

- $\quad$ Characterization of the used $10 \% \mathrm{Nb}_{2} \mathrm{O}_{5} / \mathrm{SiO}_{2}$ catalyst, to elucidate the causes for catalyst deactivation, as a result of reaction-regeneration cycle study.

- $\quad$ Experiments with methyl propionate (MeOPr) as the propionyl feedstock, instead of propionic acid.

- Investigation of reaction kinetics for vapor phase condensation reaction of formaldehyde and propionic acid, including reaction orders in formaldehyde, propionic acid, and activation energy of the reaction. The reaction kinetics will be studied for $10 \% \mathrm{Nb}_{2} \mathrm{O}_{5} / \mathrm{SiO}_{2}$ catalyst.

- Synthesis and characterization of an alkali metal catalyst supported on amorphous support for vapor phase condensation reaction of propionic acid and formaldehyde. 
The initial research on the DME extension of this contract will focus on:

- $\quad$ Tradeoff analysis comparing the DME route and methanol route (RTI three-step route). This analysis will be performed primarily by Bechtel, with experimental results from RTI and guidance from Eastman.

- DME partial oxidation and condensation reaction studies, initially with externally generated formaldehyde, to evaluate several different catalyst systems for these reactions.

\section{REFERENCES}

Gogate, M.R., J.J. Spivey, J.R. Zoeller. 1996. "Novel niobium catalysts for vapor phase condensation reactions," Patent application filed with U.S. Patents and Trademarks Office.

Gogate, M. R., J.J. Spivey, J.R. Zoeller, R.D. Colberg. 1997a. "Novel Catalysts for Environmentally Friendly Synthesis of Methyl Methacrylate," Ind. Eng. Chem. Res., 36(11), pp. 4600-4608.

Gogate, M.R., J.J. Spivey, J.R. Zoeller. 1997b. "Synthesis of methyl methacrylate by vapor phase condensation of formaldehyde with propionate derivatives," Catal. Today, 36(3), pp. 243254 .

Gogate, M.R., J.J. Spivey, J.R. Zoeller, R.D. Colberg, G.N. Choi, S.S. Tam. 1997c. "Synthesis of Methyl Methacrylate from Coal-derived Syngas," Annual Technical Report to U.S. Department of Energy, Federal Energy Technology Center, Pittsburgh, PA, pp. 1-36.

Spivey, J.J. M.R. Gogate, B.W.L. Jang, E.D. Middlemas, J.R. Zoeller, S.S. Tam and G.N. Choi. 1995. "Synthesis of acrylates and methacrylates from coal-derived syngas," In Proceedings of Contractors' Review Meeting on Coal Liquefaction and Gas Conversion, U.S. DOE/PETC, Pittsburgh, PA, pp. 385-395.

Spivey, J.J. M.R. Gogate, J.R. Zoeller, R.D. Colberg, S.S. Tam and G.N. Choi. 1996a. "Synthesis of methyl methacrylate from coal-derived syngas," In Proceedings of the First Joint Power and Fuel Systems Contractors' Conference, U.S. DOE/PETC, Pittsburgh, PA, July 9-11.

Spivey, J.J., M.R. Gogate, J.R. Zoeller, R.D. Colberg, G.N. Choi, S.S. Tam, R.E. Tischer, R.D. Srivastava. 1996b. "Novel syngas-based process for methyl methacrylate," in Proceedings of the Thirteenth Annual International Pittsburgh Coal Conference, Volume 1, pp. 559564, The University of Pittsburgh, Pittsburgh, PA.

Zoeller, J.R., E.M. Blakely, R.M. Moncier, and T.J. Dickson. 1997. "Molybdenum catalyzed carbonylation of ethylene to propionic acid and anhydride," Catal. Today, 36(3), pp. 227241. 